\title{
ViOLENT OBJECTS: THE FORMS OF PATHOS IN YAEL MARTINEZ, GLENNA Gordon AND EugÊnio Grosso's COMpOSITIONS
}

\author{
Eliza Bachega Casadei \& Mariana Duccini
}

\begin{abstract}
This article aims to investigate the photographers' Yael Martínez, Glenna Gordon and Eugenio Grosso artistic works. Their photographs highlight the violence in representation of consumer goods which evoke the extended relations between the subjects and their personal belongings. This is a way to discuss the iconological status in such objects which are then converted in other significations patterns. The study of these artists' composition strategies allows us to analyze the pathos-forms achieved by the anachronistic and dialectical montage which links the referential aspects and the decrease of iconological status in these images.
\end{abstract}

Keywords

Anachronism; arts; dialectics; pathos-forms; photography

\begin{abstract}
Resumo
O objetivo do presente artigo é estudar a obra artística dos fotógrafos Yael Martínez, Glenna Gordon e Eugenio Grosso. Em comum, suas fotografias tematizam a violência a partir da representação de objetos de consumo que evocam a relação de extensão entre o sujeito e seus pertences pessoais justamente como forma de problematizar a iconologia mesma desses objetos, que são convertidos para outras significações. A partir do estudo das estratégias de composição desses fotógrafos, iremos analisar as formas de pathos evocadas por eles através da montagem de imagens anacrônicas e dialéticas, em imagens que articulam o referencial ao esvaziamento da iconografia como ato político e memorialístico.
\end{abstract}

Palavras-chave

Anacronismo; arte; dialética; formas do pathos, fotografia

\section{BETWEEN THE ABSENCE OF BODIES, THE PRESENCE OF THE OBJECT AND THE CALL TO POLITICS: THE ICONOLOGY'S REVOCATION}

Among the basic concepts that found the epistemology of contemporary studies of consumption objects and their relation to communication, there is the assumption that they are not mere utilitarian contributions to everyday life, otherwise, they compound systems of codes and meanings that work as imaginary extensions of individuals and identity affiliations. Therein Douglas and Isherwood argue that "being fit for consumption means an object being fit to circulate as a marker for particular sets of social roles", so that "goods in their assemblage present a set of meanings more or less coherent, 
more or less intentional. They are read by those who know the code and scan them for information" (Douglas \& Isherwood, 2004, p. 28). Such as for Bourdieu (2007), objects work as markers of the differential deviations from symbolic retranslations inscribed in the habitus of social groups and in their distinction processes. These are approaches that assume an iconological perspective of everyday objects, based on the latent symbolisms of visual representations. Some artistic works, however, problematize the relationship between object and subject on a way that the theoretical point of view based on the mere iconology of objects cannot achieve the strategies and sense effects implied in these productions. Based on this assumption, the objective of this paper is to study the work of photographers who thematize consumption objects and evoke, in their productions, the extensive relationships between individuals and their personal belongings as a way of problematizing these objects iconology, which are converted to other meanings as they step into circuits of art.

As a thematic focus, we selected photographers that portrayed objects related to violent situations from different aesthetic strategies, namely Yael Martínez, Glenna Gordon and Eugenio Grosso. Martinez's images, in "The House That Bleeds", tell the stories of families from the Mexican State of Guerrero whose relatives were victims of violence, registering the objects related to family life. Gordon reports Nigerian girls kidnapped by the militant Islamic group Boko Haram, from the record of the girls' personal belongings in "Mass Abduction in Nigeria". Lastly, Grosso records in photographs the refugee's documents found on the ground at the border of the Macedonian city of Gevgelija, in "Papers: Discarded along Europe's Refugee Trails"3.

As a common pattern, the effects of pathos in the work of the three photographers refers to the disembodied violence that are materialized in the photography's objects and mark the self devoid of the subject, taking advantage of the alienation processes of the subject in the object. Such effects are correlated to the assumption that image is not only an illustrative representation of the facts that they materialize or testify, but also an instrument to affect the viewer, linking him to the dimension of suffering that makes sensible (in terms of the phenomenological aspects of these images) certain guiding lines of contemporary history.

The anomie represented by bodies' absence in these works calls for the repeal of victims' anonymity in the objects, an attempt to establish new forms of visibility and thinking 4 , by showing a different division and sharing configurations of social space.

In consonance with the contemporary modulation of the forms of realism, in which the verisimilitude of certain referential discourses (among them, the photographic one)

\footnotetext{
' Retrieved from https://www.lensculture.com/articles/yael-martinez-the-house-that-bleeds-mexico-s-disappeared\#slide-1.

${ }^{2}$ Retrieved from http://www.worldpressphoto.org/collection/photo/2015/general-news/glenna-gordon.

${ }^{3}$ Retrieved from https://www.lensculture.com/articles/

eugenio-grosso-papers-discarded-along-europe-s-refugee-trails\#slide-1

${ }^{4}$ We understand "forms of visibility and thinking" as the engendering of specific regimes of a certain historical conjuncture, which articulate the relationship between images' circulation and its possibilities of interpretation and valuation in a given social body.
} 
is not based on referentiality, but in the indices that attest a subjective presence as the ballast for what it shows (whether within the scope of the enunciative instance or in the dimension of what is understood in terms of the statement), these works are mobilized by a paradoxical dynamic: they present the reified character of framed objects at the same time as they point to the context that surpasses them, in which the sign of a singularity becomes determinant, crossing the referential aspect ("what is it?") to the subjective one ("whose is/was it?").

These are images that evoke the awareness of aesthetic experience from a specific consumption of images of violence in the circuit of artistic reception with the intention to restore a supposed identity to unnamed bodies. The question, however, is: in what terms would this experience take place? We assume that the works of these photographers do not make a call for action, in the sense of a direct intervention in reality, since:

if politics properly speaking consists in the production of subjects who give voice to the anonymous, the politics proper to art (...) consists in the elaboration of a sensible world of the anonymous, of modes of that and of $\mathrm{I}$, from which emerge the proper worlds of political wes. But inasmuch as this effect passes via the aesthetic rupture, it does not lend itself to any determinable calculation. (Rancière, 2012b, p. 65)

The dynamics of these works responds to a revocation of the iconological status of the object from the assembly of dialectical and anachronic images that use temporal mounting as a trigger of its main effects of sense. Inserted in a symbolic universe, these productions are tributary of the contemporary forms of intelligibility of the phenomena of violence - and also of the limits of what can be communicated from them, as a collective experience.

This is because if the figurativization of the victims through their metonymic fragments points to previously unprecedented configurations of a sensitive world, at the same time, the inextricable link between violence and victimized individuals (as a contemporary form of veridiction of discourses about violence itself) obscures the parameters that point to a social logic that would explain both the forms of perpetrating violence and the emergence of the victim's place as a socially constructed category.

\section{THE FORMS OF PATHOS, THE ANACHRONISM AS A COMPOSITIONAL STRATEGY AND THE DIALECTICAL IMAGE}

The failure of approaches that comprehend visual objects as coherent code systems, argues Didi-Huberman (2015, p. 240), is in suppose the "mimetic transparency of the iconic sign", "as if every picture functioned like a text, and as if every text were legible, wholly decipherable". To the comprehension that attempts to reconcile visual representations and their symbolic values from an iconological perspective, Didi-Huberman will counterpose a point of view in which the primacy of meaning gives way to a dialectical dynamics, from the refusal of an image reading (as well as the objects represented in 
it) as a simple stereotyped imagery. The author claims the need for a non-iconological semiology for image understanding, that is, "a semiology that was neither positivist (the representation as a mirror of things), nor even structuralist (the representation process as a system of signs)" (Didi-Huberman, 2015, p. 18).

In Didi-Huberman's perspective (2015, p.15), all images - including static ones presuppose a duration, so that "whenever we are before the image, we are before time". There are differentials of times operating in each image, so that it is constituted by the assembly of heterogeneous temporalities that admit anachronisms. In this case, every image is constituted by an assembly of temporal differences, from the perspective that an artist, in articulating a representation, does not refer only to signs system of his own present time, but operates an assembly of reminiscences of past systems and anachronistic meanings that are putted together with future systems of meanings that will form the reception context of this work in different temporal axes due to the anachronisms of interpretation itself). This question is related to the idea that "to be connected to the two-dimensional world is to correlate what is being seen with what has already been seen, with the pose that has already been made, with that moment in common to your family and to others families" in order to lead "the observer to receive, in mind, other images of what he keeps in memory, "without actually seeing the portrait presented to him (Leite, 2001, p. 75)"' (Pinheiro \& Cabral, 2010, p. 36).

This perspective implies recognizing that objects' meanings are not static and change along the times. It also implies that image is an impure and complex object, so that the different temporal strata of meaning systems accumulate and intertwine in the imagistic compositions. Finally, it implies we recognize the need for a "phenomenology especially attentive to the individual and collective processes of memory" since there is no possible meaning for the image "except in the montage, in the rhythmic play, in the contradiction of chronologies and anachronisms" (Didi-Huberman, 2015, p. 42).

Anachronism, therefore, is not a chronological discourse impropriety (as a positivist historiography claims), but a change from one regime of truth-building into another one. Anachronism, in this aspect, is the opening for the construction of dialectical images, insofar as it approaches heterogeneous phenomena in time and space, exposes their similarities and contiguities, provoking an opening in image itself.

Image in this way - as a dialectical assembly of meanings of surviving times - is subjected to a double regime: the pathos with the formula (Didi-Huberman, 2013b, p. 173). The expression "pathos formulas" in image (pathosformel) refers therefore to the idea of a significant trace, a trace in act, "something by which image pulsates, moves, debates in the polarity of things". It is on the union of an affective charge with an iconographic formula that is expressed in the competition of heterogeneous times in one same image. In order for the sense of historicity to be constituted, it is necessary a proper dynamics on images reading, since "there is no history behind images, but images that make history" (Mauad, 2014, p. 109). If heterogeneous times are condensed - and survive - on imagery surfaces, this is because the past (or even the future) can only be apprehended as images: whether of what no longer exists, or of what still awaits for new 
forms of perception so that its enigma condition may give rise to certain intelligibility vectors, concerning historically situated social practices.

Consequently, the referent perspective gives in to the dialectical image. In DidiHuberman's thinking (2010, p. 171), dialectical image is the one that "criticizes our ways of seeing it (...), obliges us to write this regard, not to 'transcribe it', but to constitute it". And this means that it is an image that figures beyond itself or, in other words, that requires a synthesis of different meanings beyond the ones that is exposed in its visible registry. The possibility of memory redemption inscribed in a photograph "is an essential project in the present not only because it has the power to reconsider and rewrite official history, but also because it has the capacity to confirm previously marginalized identities" (Stewart, 2016, p. 243). Beyond the visibility's scope, dialectical image operates in terms of legibility: the ability to combine past and present in order to instill, in the apparent iconographic passivity, discontinuity and shock that would engender new perception modes about history continuum. Thus, there is no "dialectical image without a critical work of memory, confronted with all that remains as to the clue of all that was lost" (Didi-Huberman, 2010, p. 174).

The specificity of Martinez, Gordon and Grosso's photographs lies in the fact that they not only rely on photographic image constitutive anachronicity, but they also construct one locus for the absence in imagery composition itself, from the emphasis on body privation and from the insistence in the self devoid of the subject (related to the presence of the object as a subjectification mark). That said, how can we interpret the objects represented in these artists' photographs? It is no longer possible to interpret them as systems of coherent and static signs that mark the continuity between the absence of the self and the presence of the object. This is because "in every historical object all times meet, collide or plastically merge into one another, bifurcate or blend into each other" (Didi-Huberman, 2015, p. 46).

More than signification systems that mark the identity contiguity between subject and object, each personal belonging represented in these photographs constitutes itself as a form of pathos, claiming a dialectical process and not a relation of pertinence between the object and the individual guided by processes of identity construction. In addition, there are the effects of indiciality engendered in these compositions, supported by a general principle that appropriates photography from a "narrowly selective interpretation" that "despite the presumption of veracity that gives all photographs authority, interest, seductiveness, the work that photographers do is no generic exception to the usually shady commerce between art and truth" (Sontag, 2001, p. 6). Therein, it is necessary to analyze, in these works, their effects of style and their effects of truth as a way of understanding their effects of pathos.

\section{EFFECTS OF STYLE, EFFECTS OF TRUTH, EFFECTS OF PATHOS}

The most violent photographs are not always those ones that refer to the graphic shock of torn bodies. The strategy of Martínez, Gordon and Grosso's works is in 
portraying violence indirectly to better explain it, by referring to banality of everyday objects to connote what is missing: the aberrant presence of the absent individual.

Martínez's photographs are motivated by a family tragedy: in 2013, three of his brothers-in-law disappeared in violent situations in Guerrero, one of the Mexican states most affected by organized crimes. In "The House that Bleeds", the photographer documents the grieving process of his own family and of the family of other missing people. In his images, it is possible to observe the relatives relation with the objects and spaces frequented by the disappeared. They are portrayed from bodies' parts and often without showing their faces.

Trauma of loss figuration is heightened by the traces of violence that invade home private space. If, contemporaneously, intimacy performativization has become one of the main modulators of subjective affirmation (the capacity of self-showing as an existential condition), with an emphasis on laborious bodies construction according to the protocols of plastic perfection and incorruptibility, Martínez is tributary of a tendency already present in certain artistic productions of 6os and 70s, in which the counterpart of the rationalist humanism chooses the fragmented bodies as an aesthetic matter, not infrequently exposed in their pure organic materiality (Sibilia, 2013). However, the arrangement of the corporal incompleteness as analogy of the photographed subjects' psychical annihilation in "The House that Bleeds" devotes to the compositional strategy an ambiguity effect: the physical/psychic dissolution of portrayed characters is "encapsulated" by the protective home environment. Consequently, in the same movement in which the presence of violence is materialized as a daily evidence in the life of these individuals, the enclosure proper to the spaces portrayed tends to limit this panorama to a subject matter, obliterating aspects of a political-social dynamics in which torture and murder are generalized, both in the organized crime actions and in the State repressive conduct, as standard responses to conflictual situations.

The remnants of violence in the bodies of those who "remain", directly affected by the dissolution of family ties, engender the production of photographs in which symbolism is triggered by the incommunicability sense correlated to brutalizing actions. As a component of this stylistic construction, many of the images use a kind of death "teatralization" in animate (though static) bodies, such as the one in which a child is almost totally wrapped in a worn towel that acts as a shroud ${ }^{6}$. Through indexing information, we know that the character is Itzel Martínez, photographer's daughter, after finishing bath. These are compositions in which the shock effect can only be relativized by contextual data, when it is made explicit the disposition of the enunciating instance to propose a metaphorical level for photographs reading. At the same time that the camera enters in intimacy spaces, it assumes a strategy that deceives the viewer: death reminiscences are engendered in a tacit, indirect way. This is how images can express a positional relation between a "consciousness" that produces the artistic creation (the authorial condition)

\footnotetext{
5 It is in the same state where the well-known episode of the disappearance of 43 students of the Normal Rural School Raúl Isidro Burgos occurred in September of 2014, due to an action of the Mexican police.

${ }^{6}$ Retrieved from https://www.lensculture.com/articles/yael-martinez-the-house-that-bleeds-mexico-s-disappeared\#slide- 1 .
} 
and the portrayed object, which condenses, in terms of a symbolism, heterogeneous meanings. The morbidity that pervades singular lives and the resistance to death in the same individuals become the expressive paradoxes of Martínez's photographs.

If the metaphoric articulation previously explained in the analysis operates by an identification procedure by similarity - meanings condensations that points to a substitution, that is, a meaning deviation in which an experience domain (the immediate victimization in virtue of violent actions) is superimposed by another one (the repercussions of this violence on a group of individuals related to the victims) -, the photographer compositional strategies do not neglect, equally, a metonymic articulation. In this case, the contiguity procedure proposes an evocation of meanings not by a substitution between different domains of experience, but by a "slip" of references, that is the activation of correspondences between expressive fragments of a totality: parts that indicate the whole. It is not a matter, in the scope of this analysis, dichotomizing the pieces of the series "The House that Bleeds" in terms of an impertinent classification that disposed them according to the metaphorical or metonymic orientation of each photograph. These two strategies are combined as principles of intelligibility in the structuring of the photographic proposition - and not just as detectable formal features on image surface. It is through the appropriation of (referential or figurative) elements that are related to a totality that is instilled the meaning deviation which is proper to art dynamics: the emergence of one domain of social experience into another.

The flower petals left over from Javier Granda's funeral7, one of the victims alluded in Martinez's series, are an example of this symbolic connection. With the figurativization of the fragments, as remnants of what no longer exists, the photograph points, at the same time, to a lost completeness and to an absence that is still productive, determining new subjective positions to those who were affected by the loss in their relation to the contingent quotidian. Petals spread on the floor, outlining a sense of incontinence: if they are insufficient to replace what is missing, they are also enough to materialize, metaphorically, the effects of this loss.

Gordon, in "Mass Abduction in Nigeria", opts for more distanced composition strategies as the presence of the first enunciative person, in contrast to Martinez's work, is remarkably less explicit in this series. Her photographs, second place winners in the "general news" category of the World Press Photo of 2015, portray objects that belonged to girls that were kidnapped by the Islamist group Boko Haram a year before. The group opposes secular education for girls and their actions include attacking schools, kidnapping students and realizing forced recruitments. School uniforms, earrings, notebooks and other belongings are organized into photographs under a neutral background, without identification (in contrast to some of Martinez's photographs, which index information about the victims or their relatives in the accompanying texts).

The non-identification of kidnapped students, however, does not work in favor of the disarticulation of the effects of pathos: they are, on the contrary, densified as an

\footnotetext{
${ }^{7}$ Retrieved from https://www.lensculture.com/articles/yael-martinez-the-house-that-bleeds-mexico-s-disappeared\#slide-1.

${ }^{8}$ Retrieved from http://www.worldpressphoto.org/collection/photo/2015/general-news/glenna-gordon.
} 
enunciative strategy through framed objects. More than testimony traces belonging to the victims, these elements compose a very particular affective universe. Wear and tear uniforms, sandals and school materials, for example, refer to the dimension of youth life and activities, prematurely destroyed by terrorist actions. Although the attribution of a specific belonging is not explicit, photographs circumscribe an entire social segment especially vulnerable to violence (the number of girls kidnapped by the terrorist group only in the action of April 14, 2014 amounts to almost 300).

By portraying preferentially objects belonging to school universe, Gordon's work articulate a criticism to the persecutions suffered by secular educational system (in free translation from the Hausa language, the expression "boko haram" means: "Western education is forbidden" 9). At the same time, the objects disposition on a black background, in addition to the sense of isolation that encompasses each one of the pieces, alludes metaphorically to the victims' helplessness and to the public's alienation (especially the Western one, to whom the photographs are preferentially intended) in relation to this vulnerability.

In this way, while "classical representation creates a continuous space in which objects and characters are arranged as discontinuous entities" (Didi-Huberman, 2015, p. 218), Gordon's images operate by the dissociation of this space, when they ask the spectator a new subject position, by moving their gaze from the forms (represented by objects) for extensive processes that are not at a connotation level, but in the constitution of the space as a problem that is supposed in the processes of remembrance. The present of his photographs is not in the sense of a presence (since they evoke the absence in the composition), but rather, in the sense of a presentation, that goes beyond the representation itself and places memory as the central axis of an experience that is constructed in the artistic creation, although it refers to wider social processes inscribed in spectators' memory. Such aspects are placed both in the absence of contextual data (which depends on the experience of a spectator who fills sense blank spaces) as in the evocation of an affective memory (that dramatizes the absent characters through present school objects and refers to a memorialistic repertoire that, in spite of all cultural differences, is also common to the spectator). It is about the constitution of a space-reminiscence that appeals to the spectator's own subjective experience in the artistic work.

Lastly, in "Papers" 10 , Grosso photographs the documents discarded by refugees on the border of Gevgelija, on the Macedonian border with Greece. According to the photographer's own description, "along that path, every day, temporary Greek documents are thrown away along with lists of names, maps and asylum requests. Immediately after leaving the country (Greece) that issued them these documents, the refugees return to their clandestine status. Their identities have to be confirmed again and again in every

\footnotetext{
9 Concerning this http://www1.folha.uol.com.br/mundo/2014/05/1449621-saiba-mais-como-surgiu-o-boko-haram-na-nigeria.shtml

10 Retrieved from https://www.lensculture.com/articles/eugenio-grosso-papers-discarded-along-europe-s-refugeetrails\#slide-1.
} 
country they enter" "1. The composition chosen by Grosso is quite minimalist, composed by the framing of the document on the floor where it was found (usually these papers bring refugees' photographs), without exact identifications about the scenario in which the narrative unfolds.

From the premise that a document, especially in the circumstances that are tangential to the issue of refugees, is the main identity mark that allows or impedes the access of an individual to better life conditions, Grosso's work thematizes the "disposable identities. There, the metaphor of violence focuses on the portrayed indices: dispensed, torn, trampled, these objects evoke a socio-historical process that accommodate precarious subjectivities, since they are separated from a community belonging so legitimized by the order of late capitalism, in which "No 'beds' are furnished for 'reembedding', and such beds as might be postulated and pursued prove fragile and often vanish before the work of 're-embedding' is complete" (Bauman, 2000, p. 33).

As in Gordon's work, it is a photographic composition that refers to the iconological aspects of personal belongings in order to deconstruct them, by referring, in an aspect that goes beyond the visible, to the memorialistic projection of the spectator, which is constructed as a composition and evoked as an experience.

A sort of second degree enunciation - the photographs taken by the artist about the photographs destroyed by the refugees themselves, which in addition to not finding any further use in the documents, still anticipate that they may become a burden - gives a sense of permanence to that has been discarded. "Papers" plays with the duration effect of photograph, based on statements whose 'first' expressiveness is delineated by the aspect of compulsory transitoriness. In addition, the character of violence inherent in these photos is coated with an aesthetic meaning: the materialized annihilation in framed objects, beyond its referential expressiveness, is another element to catalyze the perceived shock that, in a dialectical reading, demands the constitution of a regard that conjugates heterogeneous meanings in a process that exorbits the mere visibility towards images intelligibility.

\section{Conclusion}

The effect of pathos in the analyzed images will be articulated, at a first moment, from an effect of truth. On this aspect, Rancière (2007) will point out that photographs structure their regimes of truth from an incarnated dialectic that "place us before a feat of memory and presence". This is because there is a double poetic in photography that make "its images, simultaneously or separately, two things: the legible testimony of a history written on faces or objects and pure blocs of visibility, impervious to any narrativization, any intersection of meaning" (Rancière, 2007, p. 11). This is how photographic image presents itself as "cipher of a history written in visible forms and as obtuse reality, impeding meaning and history" (Rancière, 2007, p. 12).

\footnotetext{
$"$ Retrieved from https://www.lensculture.com/articles/eugenio-grosso-papers-discarded-along-europe-s-refugee-
} trails\#slide-1. 
In this perspective, the author reinterprets the famous Barthesian formulation of that-has-been. If "the name of photography's noeme will therefore be: 'that-has-been'" (Barthes, 2000, p. 77), such an assertion must be understood from the junction of an effect of truth (that, from the referent) to an effect of affection (has-been, of the interpretation, which is denied to the observer). The whole photography poetics is structured from the mystery, since "photography became an art by placing its particular techniques in the service of this dual poetics, by making the face of anonymous people speak twice - as silent witnesses of a condition inscribed directly on their features, their clothes, their life settings" and "as possessors of a secret we shall never know, a secret veiled by the very image that delivers them to us" (Rancière, 2007, p. 15). Therefore, "by projecting the immediaticity" of that-has-been "on the process of mechanical imprinting, he dispels all the mediations between the reality of mechanical imprinting and the reality of the affect that make this affect open to being experienced, named, expressed" (Rancière, 2007, p. 15).

At the same time, the dialectical and anachronistic character of images can only be pertinent if we assume, in the act of looking, an eminently subjective operation, set in motion by subjects located in time and space:

the act of seeing is not the act of a machine that perceives the real as composed by tautological evidences. The act of giving to see is not the act of offering visible evidences to a pair of eyes that unilaterally seize the "visual gift" to satisfy themselves with it unilaterally. Giving to see is always disturbing seeing, in its act, in its subject, therefore a full, disturbing open operation. (Didi-Huberman, 2010, p. 77)

If the demand for intelligibility (that surpass visibility) to subjects who stand before an image presupposes the uneasiness of seeing, then the art field seems to be one of the most favorable locus to this experience, precisely because it is capable of presenting the "world's data" according to unprecedented configurations in a common sensitive space. However, as cultural productions, photographic works are not deprived to the circulating discourses that, in each historical epoch, conforms their situated and particular truths.

When we consider that the effects of pathos in the contemplated photographs have as counterpart an obliteration of spectator critical capacity, this panorama could be explained by certain modulations of the contemporary discourses, in which the figure of the victim becomes the symbol par excellence of the violence manifestations.

The victim, in this sense, holds "a socially intelligible form of expressing the suffering associated with violence, legitimizing demands and social actions of reparation and care" (Sarti, 2011, pp. 56-57). Even in the face of the unquestionable need for victims' recognition, designation and reparation in the various contexts of violence perpetration in contemporary times, the absolutization of this category in discourses on violence tends, however, to spread, in the social body, a logic in which the experience of dissent is replaced by the mere administration/treatment of the damage - and not by its political recognition, which derives not from an identification with the victim but from a dis-identification with the perpetrators (Rancière, 1996). In other words, to delimit the 
violence problem to the field of the victim figure as a contemporary truth can delineate a form of subjectivation based on "generalized reparation", without violence being seen as a social phenomenon, directly related to a collectivity (and not as a problem restricted to the subjects).

In this context, it would be a distortion and a naivety to demand that Martinez, Gordon and Grosso's artistic creations, as well as any other photographic work itself, could be a call to action, as well it is not coherent to judge them by their supposed political emptiness. Reading images (the bonding between them and the audience) is, like any other social practice, an act crossed by veridiction parameters that modulate our forms of relationship with the world. However, these images are enough to disturb a "pacified" look based on the state of things, and they can also propel new forms of reception and intelligibility, an aspect in which the reading of an artistic work cannot be dissociated from its communicational processes.

\section{Traduzido por Eliza Bachega Casadei \& Mariana Duccini}

\section{BibLIOGRAPHIC REFERENCES}

Barthes, R. (1984). A câmara clara. Rio de Janeiro: Nova Fronteira.

Bauman, Z. (2001). Modernidade líquida. Rio de Janeiro: Jorge Zahar Ed.

Bourdieu, P. (2007). A distinção: crítica social do julgamento. São Paulo: Edusp.

Didi-Huberman, G. (2010). O que vemos, o que nos olha. São Paulo: Editora 34.

Didi-Huberman, G. (2013a). Diante da imagem. São Paulo: Editora 34.

Didi-Huberman, G. (2013b). A imagem sobrevivente. Rio de Janeiro: Contraponto.

Didi-Huberman, G. (2015). Diante do tempo. Belo Horizonte: Editora UFMG.

Douglas, M. \& Isherwood, B. (2004). O mundo dos bens: para uma antropologia do consumo. Rio de Janeiro: Editora UFRJ.

Leite, M. M. (2001). Retratos de Família. São Paulo: Editora da Universidade de São Paulo.

Mauad, A. M. (2014). Como nascem as imagens. História: Questões Q Debates, 61, 105-132. Retrieved from http://revistas.ufpr.br/historia/article/view/39008/23769

Pinheiro, P. J. S. \& Cabral, E. M. (2010). Imagens da memória: a relação entre a fotografia e a formatação screen das lembranças visuais. Comunicação e Sociedade, 17, 31-38. Retrieved from http://revistacomsoc. $\mathrm{pt} /$ index.php/comsoc/article/view/1010

Rancière, J. (1996). O desentendimento: política e filosofia. São Paulo: Editora 34.

Rancière, J. (2012a). O destino das imagens. Rio de Janeiro: Contraponto.

Rancière, J. (2012b). O espectador emancipado. São Paulo: WWF Martins Fontes. 
Sarti, C. A. (2011). Vítima como figura contemporânea. Caderno CRH, 24(61), 51-61. Retrieved from https:// portalseer.ufba.br/index.php/crh/article/view/19193/12460

Sibilia, P. (2013). Os corpos visíveis na contemporaneidade: da purificação midiática à explicitação artística. In A. Brasil; E. Morettin; \& M. Lissowski (Eds.), Visualidades Hoje (pp.119-136). Salvador: EDUFBA; Brasília: Compós.

Sontag, S. (2004). Sobre fotografia. São Paulo: Companhia das Letras.

Stewart, K. (2016). Entre a memória e o seu apagamento: O Grande Kilapy de Zézé Gamboa e o legado do colonialismo português. Comunicação e Sociedade, 29, 239-254. Retrieved from http://revistacomsoc.pt/ index.php/comsoc/article/view/2418

\section{BIOGRAPHICAL NOTES}

Eliza Bachega Casadei has a PhD in Communication Sciences from the Escola de Comunicações e Artes da Universidade de São Paulo (ECA-USP). Teacher in Program in Communication and Consumer Practices of the Escola Superior de Propaganda e Marketing (ESPM).

E-mail: elizacasadei@yahoo.com.br

ESPM - Campus Francisco Gracioso

Rua Dr. Álvaro Alvim, 123, Vila Mariana, 04018-010, São Paulo/SP, Brazil

Mariana Duccini has a PhD in Communication Sciences from the Escola de Comunicações e Artes da Universidade de São Paulo (ECA-USP). Postdoctoral researcher in Program in Multimedia of the Universidade Estadual de Campinas (UNICAMP - PNPD/ Capes).

E-mail: marianaduccini@gmail.com

Insper - Rua Quatá, 300, Vila Olímpia, 04546-042, São Paulo/SP, Brazil

* Submitted: 06-09-2016

*Accepted: 31-01-2017 